\title{
Spectroscopic determination of some trace elements as pollutants in fruit dates palm and agricultural soils at Zilfi province
}

\author{
Nawal Mahgoub Suleman \\ Department of chemistry, Zilfi Faculty of Education, Majmmah University, Zilfi, 11932 P.O 1221, Saudi Arabia
}

Email address:

nawalmahgoub@gmail.com

To cite this article:

Nawal Mahgoub Suleman. Spectroscopic Determination of Some Trace Elements as Pollutants in Fruit Dates Palm and Agricultural Soils at Zilfi Province. Science Journal of Analytical Chemistry. Vol. 2, No. 3, 2014, pp. 11-16. doi: 10.11648/j.sjac.20140203.11

\begin{abstract}
Some trace elements (Ag, Al, As, Bi, $\mathrm{Cd}, \mathrm{Co}$ and $\mathrm{Cr}$,) which could be found as pollutants in fruit dates palm and agricultural soils at Zilfi province was measured using ICP-MS. The area of study, the date palm farms found at Zilfi province, was surfed during September 2013 taking 11 samples of soil from these farms randomly. Also 11 samples of date palm fruit (fully ripe, stage of Tamer) were collected from the same farms. The $\mathrm{pH}$ and electric conductivity was measured to the soil samples. (ICP-MS) spectrophotometers were used to determine the concentrations of the elements in both soil and dates (washed and unwashed). The concentration of Ag in all samples was higher the Saskatchewan quality standards for soils .All soil samples were found to be contaminated with As, because all these concentrations of arsenic are more than Saskatchewan quality standards for soils $(11(\mathrm{mg} / \mathrm{kg}))$, and SQGE soil quality guideline for environmental health $(17(\mathrm{mg} / \mathrm{kg})$. All elements concentrations date fruits samples are less compared to literature elements concentrations. As general the concentrations of these elements are less in washed date samples compared to unwashed ones.
\end{abstract}

Keywords: Date Palm, Trace Elements, Inductively Coupled Plasma, Agricultural Soil

\section{Introduction}

Fruits are an integral part of human diet as they supply vitamins and minerals, which are important nutrients essential for human health[1]. The date palm (Phoenix dactylifera L., family Arecaceae) is one of the oldest cultivated trees in arid and semi-arid regions. The tree is valued mainly for its fruits (date) as well as for its ornamental value almost in every garden, square and avenue in Saudi Arabia. Saudi Arabia is the world's second largest producer of dates, its date production amounted to 1.07 million tons. Zilfi province with considerable agricultural potential in soil fertility and abundant water and famous for its abundant vegetation and in the introduction to that date as the spread of Palm, in Al Zilfi currently over 8000 total farm output of dates over 7360 tones and more than 2 million palm trees . Emission of heavy metals from the industries and vehicles may result in the deposition of such metals on the surface of the fruits and vegetables Since, these heavy metals might seriously damage human health e.g., decrease in immunological defense, neurological disorders, intrauterine growth retardation,
For these reasons we want to determine some trace elements as pollutants in fruit dates palm and agricultural soils at Zilfi Province by using ICP-MS spectrophotometer which represents an analytical tool with high precision.

Dates are very rich in nutritive components, carbohydrates, fats, minerals, protein, vitamins and dietary fibers[2,3] .It is preferable to consume dates at the Rutab (semi-ripe) and Tamr (fully-ripe) stages; however, the consumption of processed dates is rapidly and steadily growing [4]. Macro and trace elements play a significant role for maintaining health in humans [5]. However, non-essential trace elements like $\mathrm{Pb}, \mathrm{Cd}, \mathrm{Cr}$ and $\mathrm{Ni}$, are non-biodegradable thus, persist everywhere in the environment. These metal elements have the ability to deposit in various body organs which possess a great threat to the human health $[6,7]$. Agricultural soils irrigated with waste water get severely contaminated with heavy metals. Crops grown on such soils can accumulate a significant amount of heavy metals in different tissues [8-10] .Emission of heavy metals from the industries and vehicles may result 
in the deposition of such metals on the surface of the fruits and vegetables and contaminate them [11]. Since, these heavy metals might seriously damage human health e.g., decrease in immunological defense, neurological disorders, intrauterine growth retardation, impaired psycho-social behavior, disabilities associated with malnutrition and a high prevalence of upper gastrointestinal cancer [12] .hence, regular survey and monitoring programs of heavy metal contamination in food stuff were mainly centered for decades in developed countries[13-15]. The chemical composition of the fruits of 11 date palm cultivars grown at Riyadh region was studied during 1983 season [16]. Evaluation of sewy date palm cultivar irrigated by both treated waste water and Nile water was studied [17]. Leaves of roadside plants as bioindicator of traffic related lead pollution during different seasons in Sargodha, Pakistan have been studied [18]. Heavy metals in the fruit of date palm growing at different locations of Riyadh [19], also mineral Ion Content of date palm [20, 21] was determined at different places. Growth And heavy metals uptake by date palm grown in mono-and dual culture in heavy metals contaminated soil was determined using AAS[22]. Importance of date palms as a source of nutrition at Iraq was studied [23]. Fruit quality, nutritional value and yield of Zaghloul dates by the application of organic and/or mineral fertilizers were improved [24]. Gaseous and particulate pollutants during combustion of date palm wastes for energy recovery was measured [25]. A comparative study between mechanical and manual pollination in two premier Saudi Arabian date palm cultivars was done [26]. The typical concentrations of 17 elements in the date palm are summarized and compared with existing data in the scientific literature [27]. Distribution of heavy metals in soil and accumulation in plants at an agricultural area of Umudike, Nigeria [28]. Magnesium, calcium, copper, iron, and lead in palm oils (Elaeis guineensis) at various stages of the refining process were determined by inductively coupled plasma mass spectrometry (ICP-MS) after microwave digestion [29].

\section{Materials and Methods}

\subsection{Instrumentation}

The analytical determination of trace metals was carried out by ICP-MS (Inductively Coupled Plasma-Mass Spectrometer): ELAN 9000 (Perkin Elmer Sciex Instrument, Concord, Ontario, Canada). The table below highlights the operating conditions of the instruments used in this study. Germany. High purity water obtained from Millipore Milli-Q water purification system was used throughout the work.

\subsection{Calibration}

The ICP-MS calibration was carried out by external calibration with the blank solution and three working standard solutions $(10,20$ and $30 \mu \mathrm{g} / \mathrm{L}$ ) for all elements, starting from a $1000 \mathrm{mg} / \mathrm{L}$ single standard solutions for ICP-MS (Aristar grade, BDH laboratory supplies, England for the trace elements.

Table 1. Conditions of ELAN 9000 ICP-MS

\begin{tabular}{ll}
\hline RF power & $1250 \mathrm{~W}$ \\
Nebulizer gas flow & $0.92 \mathrm{~L} / \mathrm{min}$ \\
Lens Voltage & $9.25 \mathrm{~V}$ \\
Analog Stage Voltage & $-1762.5 \mathrm{~V}$ \\
Pulse Stage Voltage & $1050 \mathrm{~V}$ \\
Number of Replicates & 3 \\
Reading / Replicates & 20 \\
Scan Mode & Peak Hopping \\
Dwell Time & $40 \mathrm{mms}$ \\
\hline
\end{tabular}

\subsection{Sample Collection and Preparation}

The area of study, the date palm farms found at Zilfi Province, was surfed during September 2013 taking 11 samples of soil from these farms randomly(see map). Also 11 samples of date palm fruit (fully ripe, stage of Tamer) would be collected from the same farms. The date samples were divided into two groups. The first group was washed with deionized water to clean dust and deposited substances on fruit for 10 min while the second group was not washed. All samples air dried and then oven dried at $70^{\circ} \mathrm{C}$ for $48 \mathrm{~h}$ to achieve constant mass, milled and sieved through a 35 mesh screen. $1 \mathrm{~g}$ milled powder of each sample was weighed and after combusting in electrical furnace, were digested with 10 $\mathrm{ml} 2 \mathrm{~N} \mathrm{HCl}$. The resulting digest was not clear, so it was filtered through whatman filtered paper no.42. The filtered digest was transferred to a $50 \mathrm{ml}$ volumetric flask and made up to mark using deionized water. A blank digest was carried out in the same way. The trace elements (Ag, Al, As, Bi, Cd, $\mathrm{Co}$, and $\mathrm{Cr}$ ) concentrations were determined by ICP-MS (Inductively Coupled Plasma-Mass Spectrometer) [30].

\section{4. pH Determination Method}

$20 \mathrm{~g}$ of dry sieved sample were stirred with ultra pure distilled water $(50 \mathrm{ml})$ and left to equilibrate over a period of 30 minutes, and then the $\mathrm{pH}$ of each sample was measured using a microprocessor $\mathrm{pH}$ meter (HANN PH 210). Table 2. lists the Physical characteristics for fruit dates palm and soils.

\subsection{Coordinates Measuring}

The coordinates of the farms have been measured (Figure 1) using Germain( German nuvi 1410 which was made in Taiwan)

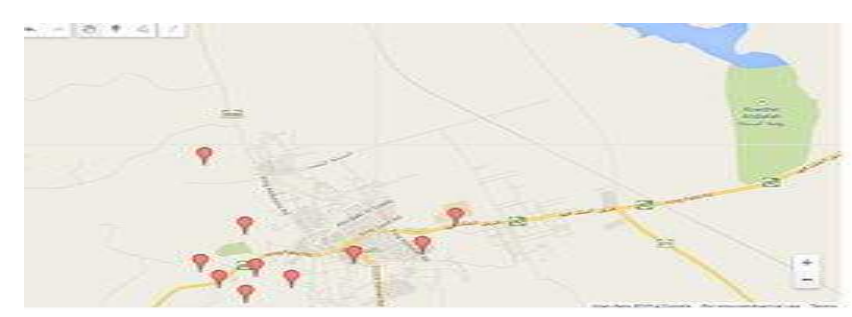

Figure 1. Date Palm Farms Under Study at Zilfi. 


\subsection{Electric Conductivity (EC)}

$20 \mathrm{~g}$ of dry sieved sample were stirred with ultra-pure distilled water $(50 \mathrm{ml})$ and left to equilibrate over a period of 30 minutes, filtered, then the electrical conductivity of each sample was measured using a conductivity meter (Crison Basic 30+EC-Meter,08323 Alella-Bacrelona(made in EU), Table (2).

Table 2. The Physical characteristics for Fruit Dates Palm and Soils

\begin{tabular}{|c|c|c|c|c|}
\hline Farm No. & Coordinates & $\mathrm{pH} \pm 0.01$ & $\mathrm{EC} \mathbf{m S} / \mathrm{cm}$ & The weight(gm) of one fruit date \\
\hline 1 & $\begin{array}{l}26^{0} 15^{\prime} .364 \mathrm{E}: \\
44^{0} 48^{\prime} .490 \mathrm{~N}:\end{array}$ & 8.00 & O.0974 & 18.8 \\
\hline 2 & $\begin{array}{l}26^{0} 19^{\prime} .302 \mathrm{E}: \\
44^{0} 48^{\prime} .839 \mathrm{~N}:\end{array}$ & 8.42 & 0.326 & 12.0 \\
\hline 3 & $\begin{array}{l}261^{0} 7^{\prime} .064 \mathrm{E}: \\
4448^{\prime} .899 \mathrm{~N}:\end{array}$ & 8.66 & 3.74 & 21.8 \\
\hline 4 & $\begin{array}{l}26^{0} 14.720 \mathrm{E}: \\
44^{0} 48.441 \mathrm{~N}:\end{array}$ & 8.45 & 0.481 & 17.3 \\
\hline 5 & $\begin{array}{l}26^{0} 17^{\prime} .437 \mathrm{E}: \\
44^{0} 47^{\prime} .944 \mathrm{~N}:\end{array}$ & 8.33 & 0.1641 & 19.3 \\
\hline 6 & $\begin{array}{l}26^{0} 16.020 \mathrm{E}: \\
44^{0} 47^{\prime} .771 \mathrm{~N}:\end{array}$ & 7.75 & 0.0861 & 18.7 \\
\hline 7 & - & 8.38 & 0.01 & 13.0 \\
\hline 8 & $\begin{array}{l}26^{0} 17^{\prime} .381 \mathrm{E}: \\
44^{0} 48^{\prime} .064 \mathrm{~N}:\end{array}$ & 8.59 & 0.1817 & 16.7 \\
\hline 9 & $\begin{array}{l}26^{0} 19^{\prime} .461 \mathrm{E}: \\
44^{0} 48^{\prime} .511 \mathrm{~N}:\end{array}$ & 8.72 & 0.44 & 23.6 \\
\hline 10 & $\begin{array}{l}26^{0} 17^{\prime} .333 \mathrm{E}: \\
44^{0} 51^{\prime} .140 \mathrm{~N}:\end{array}$ & 8.70 & 0.368 & 13.8 \\
\hline 11 & $\begin{array}{l}26^{0} 17^{\prime} .006 \mathrm{E}: \\
44^{0} 51^{\prime} .432 \mathrm{~N}:\end{array}$ & 8.37 & 0.337 & 31.7 \\
\hline
\end{tabular}

\section{Results and Discussion}

All calibration graphs are linear in the selected range of each element .The square of the correlation (r2) ranges from 0.9985-0.099999 for most of the elements in this investigation .Good precision values were obtained .The results have been reviewed in tables(3-15) and figures (2-3).

The concentrations of the elements under study in soil in $\mathrm{mg} / \mathrm{kg}$ have found as follows: $\mathrm{Ag}(0.7-42)$, $\mathrm{Al}(1628.7-6264.5), \operatorname{As}(40-59.8), \mathrm{Bi}(0.02-0.1), \mathrm{Cd}(0.08-4.2)$, $\mathrm{Co}(1.1-11.5), \mathrm{Cr}(19.2-126.2)$. The concentration of $\mathrm{Ag}$ in all samples was higher the Saskatchewan quality standards for Soils (see Table 3.12).All soil samples were found to be contaminated with As ,because all these concentrations of arsenic are more than Saskatchewan quality standards for Soils $(11(\mathrm{mg} / \mathrm{kg})$ and SQGE soil quality guideline for environmental health $(17(\mathrm{mg} / \mathrm{kg})$. The higher concentration of $\mathrm{Cd}$ was found in soil sample number (5), this value was more than both the value of Saskatchewan Tier 1 end point values for soils $(1 \mathrm{mg} / \mathrm{kg})$, or SQGE soil quality guideline for environmental health $(3.8(\mathrm{mg} / \mathrm{kg})$, also there are anther contamination of cadmium element was found in soil sample number (6) which have $\mathrm{Cd}$ concentration $(2(\mathrm{mg} / \mathrm{kg})$, compared to Saskatchewan Tier end point values for soils. The most contaminated farm was found to be soil sample (5) which have the maximum concentrations of $\mathrm{As}, \mathrm{Cd}$, and Cr.The high pollution of this farm may due to Impact on main street. Farm soil (4)which lie at inner street have maximum concentration of the elements $(\mathrm{Ag}$, and $\mathrm{CO})$. The maximum concentrations of $(\mathrm{Al}$ and $\mathrm{Bi})$ were detected in soil sample(10).The element with less concentrations compared literature values is $(\mathrm{Co})$, which has a concentration $(11.5 \mathrm{mg} / \mathrm{kg})$. There are no criteria in Saskatchewan Tier end point values for soils or SQGE soil quality guideline for environmental health for the concentrations of $\mathrm{Al}$ and $\mathrm{Bi}$. The minimum concentrations of the elements ( $\mathrm{As}, \mathrm{Cd}$, and Co) were found in farm soil(3), which lie away from the main streets .Soil sample(9) contains the minimum concentrations values of ( $\mathrm{Ag}$ and $\mathrm{Cr}$ ), while farm(7) contains the minimum concentrations of $(\mathrm{Al})$. The minimum concentrations of (Bi) was found in the soil sample (2).

Table 3. Elements Mean Concentrations $(\mathrm{mg} / \mathrm{kg})$ in Farm No.1

\begin{tabular}{llll}
\hline Element & soil sample & $\begin{array}{l}\text { Unwashed } \\
\text { Date Sample }\end{array}$ & $\begin{array}{l}\text { Washed Date } \\
\text { Sample }\end{array}$ \\
\hline $\mathrm{Ag}$ & 2.1 & 1.2 & 1 \\
$\mathrm{Al}$ & 2333.8 & 152.9 & 48.3 \\
$\mathrm{As}$ & 40.7 & 6.2 & 5.2 \\
$\mathrm{Bi}$ & 0.03 & 0.008 & 0.006 \\
$\mathrm{Cd}$ & 1 & 0.15 & 0.18 \\
$\mathrm{Co}$ & 1.9 & 0.13 & 0.12 \\
$\mathrm{Cr}$ & 35.2 & 15.5 & 6.2 \\
\hline
\end{tabular}

Table 4. Elements Mean Concentrations $(\mathrm{mg} / \mathrm{kg})$ in Farm No.2

\begin{tabular}{llll}
\hline Element & soil sample & $\begin{array}{l}\text { Unwashed Date } \\
\text { Sample }\end{array}$ & $\begin{array}{l}\text { Washed Date } \\
\text { Sample }\end{array}$ \\
\hline $\mathrm{Ag}$ & 2.9 & 0.6 & 0.82 \\
$\mathrm{Al}$ & 2229.5 & 56.5 & 35.2 \\
$\mathrm{As}$ & 46.7 & 5.4 & 4.4 \\
$\mathrm{Bi}$ & 0.02 & 0.006 & 0.006 \\
$\mathrm{Cd}$ & 0.7 & 0.12 & 0.06 \\
$\mathrm{Co}$ & 4.4 & 0.05 & 1.1 \\
$\mathrm{Cr}$ & 30.9 & 8.2 & 6.2 \\
\hline
\end{tabular}


Table 5. Elements Mean Concentrations $(\mathrm{mg} / \mathrm{kg})$ in Farm No.3

\begin{tabular}{llll}
\hline Element & soil sample & $\begin{array}{l}\text { Unwashed } \\
\text { Date Sample }\end{array}$ & $\begin{array}{l}\text { Washed Date } \\
\text { Sample }\end{array}$ \\
\hline $\mathrm{Ag}$ & 2.7 & 42 & 1.1 \\
$\mathrm{Al}$ & 1846.7 & 4363.7 & 82.7 \\
$\mathrm{As}$ & 40 & 44.4 & 4.3 \\
$\mathrm{Bi}$ & 0.03 & 0.06 & 0.006 \\
$\mathrm{Cd}$ & 0.08 & 0.6 & 0.06 \\
$\mathrm{Co}$ & 1.1 & 11.5 & 1.3 \\
$\mathrm{Cr}$ & 25.5 & 125.2 & 15.4 \\
\hline
\end{tabular}

Table 6. Elements Mean Concentrations ( $\mathrm{mg} / \mathrm{kg}$ ) in Farm No.4

\begin{tabular}{llll}
\hline Element & soil sample & $\begin{array}{l}\text { Unwashed } \\
\text { Date Sample }\end{array}$ & $\begin{array}{l}\text { Washed Date } \\
\text { Sample }\end{array}$ \\
\hline $\mathrm{Ag}$ & 2.7 & 0.92 & 0.95 \\
$\mathrm{Al}$ & 1846.7 & 94.5 & 42 \\
$\mathrm{As}$ & 40 & 5 & 4.1 \\
$\mathrm{Bi}$ & 0.03 & 0.004 & 0.008 \\
$\mathrm{Cd}$ & 0.08 & 0.09 & 0.08 \\
$\mathrm{Co}$ & 1.1 & 0.08 & 0.05 \\
$\mathrm{Cr}$ & 25.5 & 12.2 & 6 \\
\hline
\end{tabular}

Table 7. Elements Mean Concentrations ( $\mathrm{mg} / \mathrm{kg}$ ) in Farm No.5

\begin{tabular}{llll}
\hline Element & soil sample & $\begin{array}{l}\text { Unwashed Date } \\
\text { Sample }\end{array}$ & $\begin{array}{l}\text { Washed Date } \\
\text { Sample }\end{array}$ \\
\hline $\mathrm{Ag}$ & 3.4 & 0.4 & 0.8 \\
$\mathrm{Al}$ & 3067.4 & 24.6 & 34.3 \\
$\mathrm{As}$ & 59.8 & 6 & 5.0 \\
$\mathrm{Bi}$ & 0.07 & 0.005 & 0.006 \\
$\mathrm{Cd}$ & 4.2 & 0.2 & 0.12 \\
$\mathrm{Co}$ & 1.9 & 0.03 & 0.04 \\
$\mathrm{Cr}$ & 126.2 & 4.1 & 5.1 \\
\hline
\end{tabular}

The concentrations of the elements under study in date palm fruit in $\mathrm{mg} / \mathrm{kg}$ have been found as follows: $\mathrm{Ag}$ (0.3-1.2) , $\mathrm{Al}(24.6-152.9), \mathrm{As}(4.3-6.5), \mathrm{Bi}(0.004-0.008)$, $\mathrm{Cd}(0.03-0.2), \quad \mathrm{Co}(0.03-1.6)$, and $\operatorname{Cr}(4.1-15.5)$. The most contaminated date sample compared to the other samples under study was sample (1), as it contains the maximum concentrations of the elements( $\mathrm{Ag}, \mathrm{Al}, \mathrm{Bi}$, and $\mathrm{Cr})$.Date sample(10) contains the maximum concentrations of (As and $\mathrm{Bi}), \mathrm{Bi}$ maximum value also found in $\operatorname{samples}(11,9$, and 7). The maximum value of $\mathrm{Cd}$ was found in date sample (5), and the farm itself contains the highest concentration of the same element in soil. The maximum concentration of (Co) was found in date samples (8). All elements concentrations date fruits samples are less compared to literature elements concentrations. As general the concentrations of these elements are less in washed date samples compared to unwashed ones.

Table 8. Elements Mean Concentrations( $\mathrm{mg} / \mathrm{kg}$ ) in Farm No.6

\begin{tabular}{llll}
\hline Element & soil sample & $\begin{array}{l}\text { Unwashed } \\
\text { Date Sample }\end{array}$ & $\begin{array}{l}\text { Washed Date } \\
\text { Sample }\end{array}$ \\
\hline $\mathrm{Ag}$ & 3.1 & 0.5 & 1.9 \\
$\mathrm{Al}$ & 3888.8 & 28.5 & 43 \\
$\mathrm{As}$ & 59.4 & 6.2 & 3.3 \\
$\mathrm{Bi}$ & 0.07 & 0.007 & 0.006 \\
$\mathrm{Cd}$ & 2 & 0.08 & 0.06 \\
$\mathrm{Co}$ & 2.4 & 0.05 & 0.07 \\
$\mathrm{Cr}$ & 67.7 & 5.2 & 9.2 \\
\hline
\end{tabular}

Table 9. Elements Mean Concentrations $(\mathrm{mg} / \mathrm{kg})$ in Farm No.7

\begin{tabular}{llll}
\hline Element & soil sample & $\begin{array}{l}\text { Unwashed Date } \\
\text { Sample }\end{array}$ & $\begin{array}{l}\text { Washed Date } \\
\text { Sample }\end{array}$ \\
\hline $\mathrm{Ag}$ & 1.3 & 0.5 & 1.5 \\
$\mathrm{Al}$ & 1628.7 & 56.4 & 66.4 \\
$\mathrm{As}$ & 41.6 & 5 & 4.7 \\
$\mathrm{Bi}$ & 0.03 & 0.008 & 0.007 \\
$\mathrm{Cd}$ & 0.4 & 0.05 & 0.07 \\
$\mathrm{Co}$ & 1.5 & 1.1 & 0.09 \\
$\mathrm{Cr}$ & 20.7 & 5.3 & 5.8 \\
\hline
\end{tabular}

Table 10. Elements Mean Concentrations $(\mathrm{mg} / \mathrm{kg})$ in Farm No.8

\begin{tabular}{llll}
\hline Element & soil sample & $\begin{array}{l}\text { Unwashed } \\
\text { Date Sample }\end{array}$ & $\begin{array}{l}\text { Washed Date } \\
\text { Sample }\end{array}$ \\
\hline $\mathrm{Ag}$ & 3.1 & 0.5 & 1.9 \\
$\mathrm{Al}$ & 3888.8 & 28.5 & 43 \\
$\mathrm{As}$ & 59.4 & 6.2 & 3.3 \\
$\mathrm{Bi}$ & 0.07 & 0.007 & 0.006 \\
$\mathrm{Cd}$ & 2 & 0.08 & 0.06 \\
$\mathrm{Co}$ & 2.4 & 0.05 & 0.07 \\
$\mathrm{Cr}$ & 67.7 & 5.2 & 9.2 \\
\hline
\end{tabular}

Table 11. Elements Mean Concentrations (mg/kg) in Farm No.9

\begin{tabular}{llll}
\hline Element & soil sample & $\begin{array}{l}\text { Unwashed Date } \\
\text { Sample }\end{array}$ & $\begin{array}{l}\text { Washed } \\
\text { Date Sample }\end{array}$ \\
\hline $\mathrm{Ag}$ & 0.7 & 0.5 & 1.6 \\
$\mathrm{Al}$ & 2313.9 & 56.4 & 80 \\
$\mathrm{As}$ & 49.9 & 5 & 2.3 \\
$\mathrm{Bi}$ & 0.03 & 0.008 & 0.001 \\
$\mathrm{Cd}$ & 0.3 & 0.05 & 0.04 \\
$\mathrm{Co}$ & 1.8 & 1.1 & 0.08 \\
$\mathrm{Cr}$ & 19.2 & 5.3 & 10.2 \\
\hline
\end{tabular}

Table 12. Elements Mean Concentrations ( $\mathrm{mg} / \mathrm{kg}$ ) in Farm No.10

\begin{tabular}{llll}
\hline Element & soil sample & $\begin{array}{l}\text { Unwashed } \\
\text { Date Sample }\end{array}$ & $\begin{array}{l}\text { Washed Date } \\
\text { Sample }\end{array}$ \\
\hline $\mathrm{Ag}$ & 25.3 & 25.3 & 0.3 \\
$\mathrm{Al}$ & 6264.5 & 6264.5 & 31.2 \\
$\mathrm{As}$ & 53.2 & 53.2 & 6.5 \\
$\mathrm{Bi}$ & 0.1 & 0.1 & 0.008 \\
$\mathrm{Cd}$ & 0.2 & 0.2 & 0.03 \\
$\mathrm{Co}$ & 4.2 & 4.2 & 0.9 \\
$\mathrm{Cr}$ & 36.2 & 36.2 & 4.9 \\
\hline
\end{tabular}

Table 13. Elements Mean Concentrations $(\mathrm{mg} / \mathrm{kg})$ in Farm No.11

\begin{tabular}{llll}
\hline Element & soil sample & $\begin{array}{l}\text { Unwashed } \\
\text { Date Sample }\end{array}$ & $\begin{array}{l}\text { Washed Date } \\
\text { Sample }\end{array}$ \\
\hline $\mathrm{Ag}$ & 5.4 & 0.7 & 7.9 \\
$\mathrm{Al}$ & 5843.8 & 75.2 & 34 \\
$\mathrm{As}$ & 43.9 & 5.6 & 7.6 \\
$\mathrm{Bi}$ & 0.07 & 0.008 & 0.02 \\
$\mathrm{Cd}$ & 0.4 & 0.08 & 0.14 \\
$\mathrm{Co}$ & 3.6 & 1 & 0.04 \\
$\mathrm{Cr}$ & 43.2 & 5 & 6.5 \\
\hline
\end{tabular}


Table 14. Comparison between the concentrations found in the Soil Sample Ruled by Literature

\begin{tabular}{|c|c|c|c|c|c|c|}
\hline Element & $\begin{array}{l}\text { Maximum } \\
\text { Values Found } \\
(\mathrm{mg} / \mathrm{kg}) \\
\end{array}$ & $\begin{array}{l}\text { Soil sample } \\
\text { number }\end{array}$ & $\begin{array}{l}\text { minimum Values } \\
\text { Found (mg/kg) }\end{array}$ & Soil sample number & $\begin{array}{l}\text { Saskatchewan } \\
\text { Environmental } \\
\text { Quality Standard } \\
\end{array}$ & $\begin{array}{l}\text { SQGE } \\
\text { soil quality guideline for } \\
\text { environmental health }\end{array}$ \\
\hline $\mathrm{Ag}$ & 42 & 4 & 0.7 & 9 & 0.5 & - \\
\hline $\mathrm{Al}$ & 6264.5 & 10 & 1628.7 & 7 & $\mathrm{nc}$ & - \\
\hline As & 59.8 & 5 & 40 & 3 & 11 & 17 \\
\hline $\mathrm{Bi}$ & 0.1 & 10 & 0.02 & 2 & - & - \\
\hline $\mathrm{Cd}$ & 4.2 & 5 & 0.08 & 3 & 1 & 3.8 \\
\hline $\mathrm{Co}$ & 11.5 & 4 & 1.1 & 3 & 19 & - \\
\hline $\mathrm{Cr}$ & 126.2 & 5 & 19.2 & 9 & 64 & 64 \\
\hline
\end{tabular}

Table 15. Comparison between the concentrations found for Dates Samples and the Maximum Levels Ruled by Literature

\begin{tabular}{|c|c|c|c|c|c|}
\hline Element & $\begin{array}{l}\text { minimum Values Found } \\
\text { for Dates (mg/kg) }\end{array}$ & $\begin{array}{l}\text { Soil sample } \\
\text { number }\end{array}$ & $\begin{array}{l}\text { Maximum Values Found } \\
\text { for Dates }(\mathrm{mg} / \mathrm{kg})\end{array}$ & $\begin{array}{l}\text { Soil sample } \\
\text { number }\end{array}$ & $\begin{array}{l}\text { SQGHH soil quality guideline for } \\
\text { human health. }\end{array}$ \\
\hline $\mathrm{Ag}$ & 0.3 & 10 & 1.2 & 1 & - \\
\hline Al & 24.6 & 5 & 152.9 & 1 & - \\
\hline As & 4.3 & 4 & 6.5 & 10 & 12 \\
\hline $\mathrm{Bi}$ & 0.004 & 4 & 0.008 & $11,10,9,7,1$ & - \\
\hline $\mathrm{Cd}$ & 0.03 & 10 & 0.2 & 5 & 1.4 \\
\hline $\mathrm{Co}$ & 0.03 & 5 & 1.6 & 8 & - \\
\hline $\mathrm{Cr}$ & 4.1 & 5 & 15.5 & 1 & 220 \\
\hline
\end{tabular}

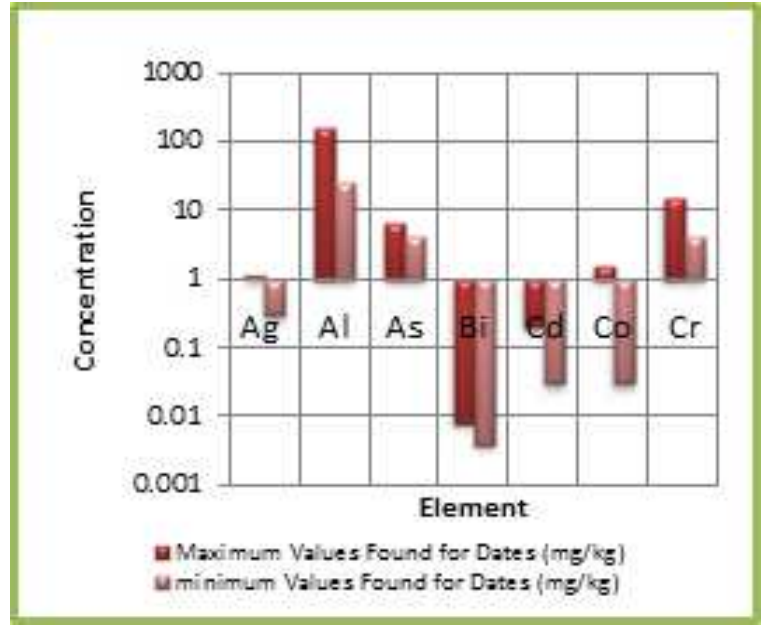

Figure 2. Comparison between minimum and maximum concentrations found in the Soil Samples.

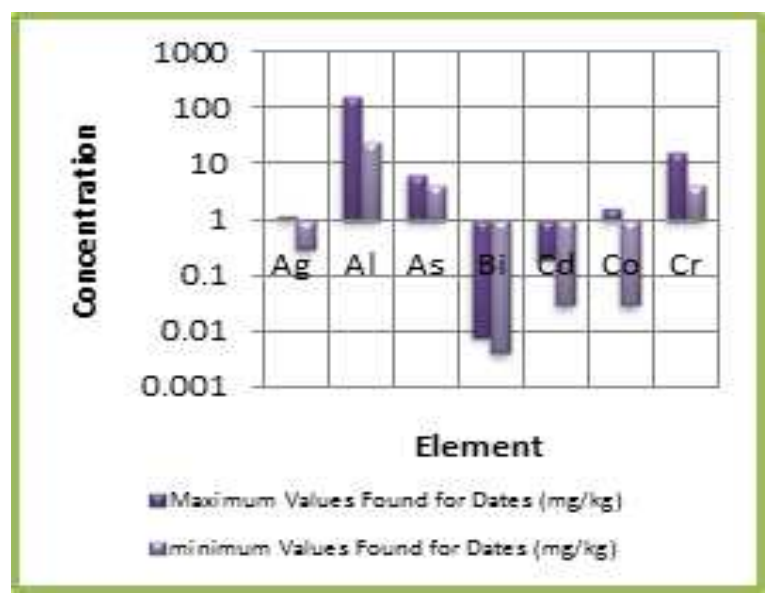

Figure 3. Comparison between minimum and maximum concentrations found for Dates Samples

\section{Conclusions}

1-All soil samples were found to be contaminated with As

2-The most contaminated farm was found to be soil sample (5) which have the maximum concentrations of As, $\mathrm{Cd}$, and $\mathrm{Cr}$. The high pollution of this farm may due to Impact on main street.

3-The minimum concentrations of the elements (As, Cd, Co.) were found in farm soil(3), which lie away from the main streets .

4-The most contaminated date sample compared to the other samples under study was sample (1),as it contains the maximum concentrations of the elements $(\mathrm{Ag}, \mathrm{Al}, \mathrm{Bi}$, and $\mathrm{Cr})$.

5-All elements concentrations date fruits samples are less compared to literature elements concentrations .

6-As general the concentrations of these elements are less in washed date samples compared to unwashed ones.

7- The presence of farms away from sources of pollution resulting from the movement of cars and factories

\section{Acknowledgements}

The authors gratefully thank Majmmah University for their financial support. Also express gratitude to Mr Kamal O.Ahmed at King Saud University for providing the support to complete this work.

\section{References}

[1] Mumzuroglu, O., F. Karatas and H. Geekil. 2003. The vitamin and selenium contents of apricot fruit of different varieties cultivated in different geographical regions. Food Chem., 83:205-212. 
[2] Al-Shahib, W., Marshall, R.J., Int. J. Food Sci. Nutr.54 (4), 247-259, 2003.

[3] Fayadh, J.M., Al-Showiman, J. Chem. Soc. Pak. 12 (1), 84-103. 1990

[4] Al-Hooti, S., Sidhu, J.S., Al-Otaibi, J., Al-Ameeri, H., J. Food Process. Pres. 21 (1), 55-68. 1997.

[5] Anonymous. 2000. Official Methods of Analysis. The Association of the Official Analytical Chemists. 17th. Ed.Arlington Virginia USA.

[6] Singh, K.P., D. Mohan, S. Sinha and R. Dalwani. 2004. Impact assessment of treated/untreated waste water toxicants discharged by sewage treatment plants on health, agricultural and environmental quality in the waste water disposal areas. Chemosphere, 55: 227-255.

[7] Chen, Y., C. Wang and Z. Wang. 2005. Residues and source identification of persistent organic pollutants in farmland soils irrigated by effluents from biological treatment plants. Environ.Intern., 31: 77-783.

[8] Khairiah, T., M.K. Zalifah, Y.H. Yin and A. Aminah. 2004. The uptake of heavy metas by fruit type vegetables grown in selected agricultural areas. Pak. J. Biol. Sci., 7: 1438-1442.

[9] Chojnacha, K., A. Chojnacki, H. Gorecka and H. Gorecki. 2005. Bioavailability of heavy metalsfrom polluted soils to plants. Sci. Total Environ., 333: 175-182.

[10] Muchuweti, M., J.W. Birkett, E. Chinyanga, R. Zvauya, M.D. Scrimshah and J. Lester. 2006. Heavy metal content of vegetables irrigated with mixture of waste water and sewage sludge in Zimbabwe, implications for human health. Agri. Ecosys. Environ., 112: 41-48.

[11] Jassir, M.S., A. Shaker and M.A. Khaliq. 2005. Deposition of heavy metals on green leafy vegetables sold on roadsides of Riyadh city, Saudi Arabia. Bull. Environ. Contam. Toxico., 75:1020-1027.

[12] Arora, M., K. Bala, R. Shweta, R. Anchal, K. Barinder and M. Neeraj. 2008. Heavy metal accumulation in vegetables irrigated with water from different sources. Food Chem., 111: 811-815.

[13] Jorhem, L. and B. Sundstroem. 1993. Levels of lead, cadmium, zinc, copper, nickel, chromium,manganese and cobalt in foods on the Swedish market, 1983-1990. J. Food Comp. Anal. 6:223-241.

[14] Milacic, R. and B. Kralj. 2003. Detrmination of $\mathrm{Zn}, \mathrm{Cu}, \mathrm{Cd}$,
$\mathrm{Pb}, \mathrm{Ni}$ and $\mathrm{Cr}$ in some Solvenian Food stuffs. Euro. Food Res. Technol., 217:211-214.

[15] Saracoglu, S., M. Tuzen, D. Mendil, M. Soylak, L. Elci and M. Dogan. 2004. Heavy metal content of hard biscuits produced in Turkey. Bull. Environ. Contam. Toxicol., 73: 264-269.

[16] F.A. Saad, M.A. Shaheen and M.A. BachaProc. Saudi BioI. Soc.. 9. pp. 25-33 (1986)

[17] Z. A. M. Abu-Rekab and A.Y. El-Kerdany,4 th Conference on Recent Technologies in Agriculture ,2009

[18] Naima H. N., et .al,,African Journal of Environmental Science and Technology Vol. 4(11), pp. 770-774, November, 2010

[19] Ibrahim M. Aldjain a, Mohamed H. Al-Whaibi b, *, Salim S. Al-Showiman c,Manzer H. Siddiqui bSaudi Journal of Biological Sciences (2011) 18(2), 175-180.

[20] Ahmed Y. A,and, AhmeS. H. ,J. Agric. Food Chem., 2004, 52, $6522-6525$

[21] Imdadullah M.Z.,et.al,J.Chem.Soc.Pak.,Vol.32(1)2010

[22] Mohebi A. H., World Applied Sciences Journal 15 (3): 429-435, 2011

[23] Al-Gboori B. K. Agricultura Tropica Et Subtropica, 43 (4) 2010

[24] H.A. Marzouka, andH.A. Kassemb, Scientia Horticulturae 127 (2011) 249-254

[25] Yassine El Mayet.al,,, ,Aerosol and Air Quality Research, 12: 814-825, 2012

[26] N. A. Al-Wusaiba ,et.al, Indian Journal of Science and Technology, Vol. 5 No. 4 , $2487,(2012)$.

[27] Williams, John R; Pillay, Avin E. Journal of Environmental Protection 2.5 (Jul 2011): 592-600.

[28] Princewill C. Ogbonnaa*, Chibuike Odukaesiemea \& Jaime A. Teixeira da Silvab, Chemistry and Ecology, Volume 29, Issue 7, 2013, pages 595-603

[29] Aleksandra Szydłowska-Czerniak *†, Konrad Trokowski †, György Karlovits §, and Edward Szłyk †,J. Agric. Food Chem., 2013, 61 (9), pp 2276-2283

[30] Ataabadi, M. H., and Najafi, P., African Journal of Biotechnology Vol. 11(19), pp. 4391-4395, 6 March, 2012 